\title{
Spectral Analysis of Rainfall Anomaly in Tanjung Priok
}

\author{
Tyas T Pujiastuti, Nurjaman, Sugeng Indarto \\ \{tyas.pujiastuti@bmkg.go.id\} \\ Indonesia agenccy for meteorology, climatology and geophysics, Jl. Angkasa I No.2 Kemayoran, \\ Jakarta, 10720, Indonesia
}

\begin{abstract}
Rainfall is the most important weather element that played critical role in human life. Located in tropical region, Indonesia has great variability of rainfall that influenced by various factors including global, regional, and local scale phenomena. To achieve better rainfall prediction accuracy, we have to understand factors that contribute to rainfall formation process. In this study, we conducted spectral analysis of rainfall in Tanjung Priok. As the busiest port in the country, there was a demand of high precision weather forecast in Tanjung Priok region. Spectral analysis was used to recognize rainfall pattern in the location. The result showed that rainfall in Tanjung Priok followed the annual cycle, while rainfall anomalies observed six periods of 19 dasarians, 31 dasarians, 3 dasarians, 42 dasarians, 114 dasarians, and 228 dasarians. These periods were indicated as the period of ITCZ, Madden-Jullian Oscillation, dipole mode, and El Nino / La Nina.
\end{abstract}

Keywords: Rainfall, Spectral Analysis, Tanjung Priok.

\section{Introduction}

Rainfall is one of weather element that has high variation, especially in tropic regions. One of the factors that influence rainfall variation in Indonesia is topographic variation which consists of islands, hills, valleys, and mountains. Regarding to the fact that Indonesia has wider water region than land region, there are many coastal areas in Indonesia. The weather characteristics especially rainfall pattern in this region are certainly different from the weather on land that far from the ocean.

An accurate weather forecast in coastal region is critical for supporting activities in the port, and marine transportation safety. Tanjung Priok, located in Indonesia's capital city, has the busiest port in the country that demand highly accurate weather information including rainfall forecast. Knowledge of factors influenced rainfall formation in one specific region is needed in order to provide high precision forecast in local area. Related to this matter, statistical analysis is the most reliable method that has been widely used to determine the pattern and/or factors influenced pattern formation.

Spectral analysis has been widely used for data analysis in atmospheric sciences for characterizing and analyzing sequenced data. This analysis provide information about periodic part and hidden periodicity of time series data. Studies about rainfall periodicity in tropical 
region showed an interaction among various disturbance on global and regional scale (Fleer, 1981, Hermawan, 2007, Suryantoro, 2004). Therefore information about interaction of global and regional scale influence to specific location is important. In this study, spectral analysis is applied to 10-year rainfall sequenced data in order to get information about its pattern and factors that indicated influence the rainfall formation in coastal area especially Tanjung Priok. The result then can be used to support daily weather forecast conducted in Tanjung Priok Marine Meteorological Station.

\section{Material and methods}

In this study, we used daily rainfall data for 19 years starting from 2000 to 2018. Data was obtained from Tanjung Priok Marine Meteorological Station which is located at $06^{\circ} 06^{\prime} \mathrm{LS}$ and $106^{\circ} 52^{\prime} \mathrm{BT}$ with $2 \mathrm{~m}$ of Station elevation. This daily rainfall data is then processed into the form of dasarian rainfall (10 days), including the amount of rainfall during first ten days (day 1 - 10) called dasarian I, the second ten days (day 11 - 20) called dasarian II, and the remained (day 21 - 30) called dasarian III.

Spectral analysis is conducted using Statistica software by applying the sequenced data into fourier function as harmonic function, following equation as follows:

$\mathbf{x}_{\mathbf{t}}=\frac{\mathrm{a} 0}{2}+\sum\left[\mathbf{a}_{\mathrm{k}} \mathbf{x} \cos \left(\lambda_{\mathrm{k}} \mathbf{x}\right)+\mathbf{b}_{\mathrm{k}} \mathbf{x} \sin \left(\lambda_{\mathrm{k}} \mathbf{x} \mathbf{t}\right)\right] \quad$ for $\mathrm{k}=1$ until $\mathrm{q}$

where:

$\mathrm{x}_{\mathrm{t}}=\mathrm{t}^{\mathrm{th}}$ data expressed in fourier form

$\mathrm{t}=$ time $=1,2,3, \ldots \ldots . \mathrm{n}$

$\mathrm{n}=$ the amount of data

$\mathrm{a}_{0}=$ means of all data data $=\frac{1}{n} \sum \mathrm{y}(\mathrm{t})$

$\mathrm{a}_{\mathrm{k}}=$ regression coefficient $=\frac{2}{n} \sum \mathrm{y}_{\mathrm{t}} \cos \left(\frac{2 \pi \mathrm{kt}}{n}\right)$

$b_{k}=$ regression coefficient $=\frac{2}{n} \sum y_{t} \sin \left(\frac{2 \pi k t}{n}\right)$

$\mathrm{y}_{\mathrm{t}}=$ time series data

$\lambda_{\mathrm{k}}=$ angle frequency (in radian per time unit) $=2 \Pi v_{\mathrm{k}}$

$v_{\mathrm{k}}=$ the amount of cycles per time unit $=\frac{\mathrm{k}}{q}$

$\mathrm{q}=\frac{\mathrm{n}}{2}$ if $\mathrm{n}$ evennumber; $\mathrm{q}=\frac{n-1}{2}$ if $\mathrm{n}$ odd number 
After sequenced data in fourier function form is obtained, then to estimate its spectrum value we used weighted periodogram function, where weighting is conducted using spectral window. In this study, Parzen window was chosen for the analysis. Hadi (1987) concluded that Parzen window, resulting a sharper spectral graph than other windows. The weighted periodogram function is as follows:

$\mathrm{F}(\lambda \mathrm{k})=\mathrm{I}(\lambda \mathrm{k}) \mathrm{x} \mathrm{w}$

where:

$\mathrm{w}=$ Weighting function (spectral window)

Periodogram is spectrum function on frequency, while in this study, to get periodicity information spectrum function is calculated over period. The period is calculated using formula Period $=\frac{1}{v \mathrm{k}}$

\section{Results and Discussion}

Spectral analysis on sequenced rainfall data on Tanjung Priok showed in fig.1. On this graph, there was one dominant spectral peak on 36 dasarians or 360 days. According to Hadi (1987), most of Indonesian region has dominant peak of 1-year due to strong monsun influence on the formation of rainfall pattern.

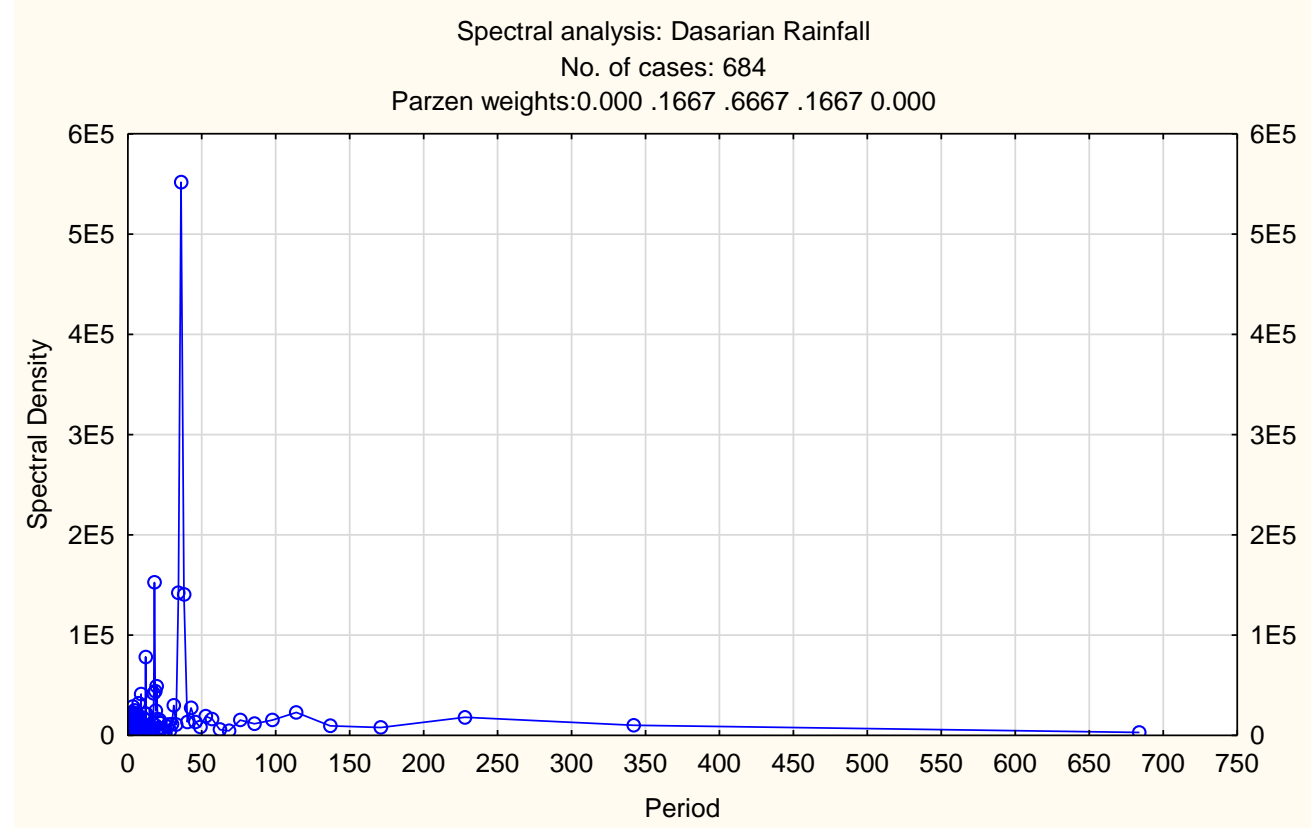

Fig. 1. Spectral graph with annual peak

From above graph, there was no information about long-term rainfall fluctuations due to the presence of a dominant annual peak while the expected peaks cannot be observed because 
of coincidence. Therefore the annual peak must be removed. In order to eliminate the annual peak, we used rainfall anomaly data which was obtained by substracting rainfall data by its average in dasarian form.

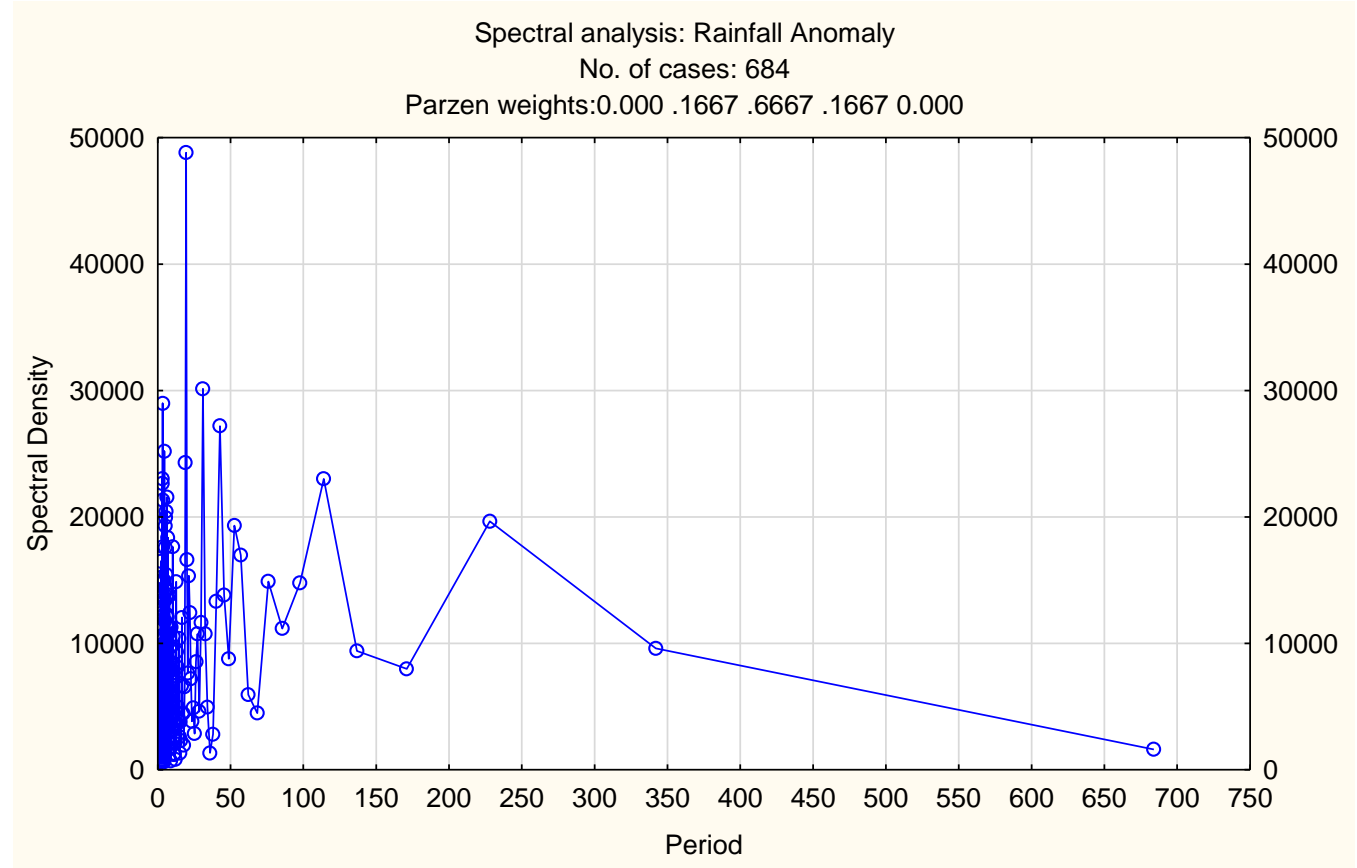

Fig. 2. Spectral graph of removed annual peak

Spectral graph of the anomaly data showed in fig.2. From the graph, there are six dominant peaks that we will analyse further:

Table 1. Dominant spectral peaks

\begin{tabular}{ccc}
\hline No. & Spectral Peak & Period (dasarian) \\
\hline $\mathbf{1}$ & Spectral Peak I & 19,54 \\
\hline $\mathbf{2}$ & Spectral Peak II & 31,09 \\
\hline $\mathbf{3}$ & Spectral Peak III & 3,40 \\
\hline $\mathbf{4}$ & Spectral Peak IV & 42,75 \\
\hline
\end{tabular}




\begin{tabular}{ccc}
\hline $\mathbf{5}$ & Spectral Peak V & 114 \\
\hline $\mathbf{6}$ & Spectral Peak VI & 228 \\
\hline
\end{tabular}

The spectral peak I was observed in a 19 dasarian period or around 190 days. This period appeared most dominant when compared to periods at other spectral peaks. Such a period according to Eddy [3] is an indication of semi-annual oscillation. Eddy stated that this semiannual oscillation is possible in relation to the movement of the ITCZ (Inter Tropical Convergence Zone) towards the north and south during the months of October - November and March - April [3]. According to Fleer[1], rainfall in the tropics is strongly influenced by variations in the location of ITCZ, this was stated by Heribert based on the results of research he conducted on rain in the tropics using spectral cross analysis. According to Hidayat [5], rainfall pattern in Soekarno Hatta meteorological station situated in aerodrome near the coast of Jakarta was influenced by ITCZ. This result based on wavelet analysis of long term rainfall data measured on Soekarno Hatta meteorological station.

The second dominant spectral peak was observed in a period of about 31 dasarians or around 310 days. Such a period was observed on Fleer study, led him to conclude that some oscillation with 10 months period was influenced rainfall in wide area including tropical region.

The third dominant spectral peak was observed in a period of about 3 dasarians or around 30 days.In the study, conducted by Arief [4] regarding the relationship of madden-julian oscillations to convective cloud activity patterns and rainfall in Sumatra, this period was associated with madden-julian oscillation (MJO). Arief argues that madden-julian oscillations can influence patterns of convective cloud activity and rainfall patterns in an area. However, the influence of this oscillation is not dominant and can be mitigated by the phenomenon of other oscillations such as annual oscillations, semi-annual oscillations, as well as other oscillations.

The fourth dominant spectral peak is observed in a period of about 42 dasarians or around 420 days. In a study conducted by Hermawan[3] regarding the effect of dipole mode on normal rainfall in the western and southern Sumatra regions, this period was associated with dipole mode. However, to determine whether positive dipole mode or negative dipole mode has an effect on rainfall patterns in Tanjung Priok, further studies need to be conducted.

The fifth dominant period was observed at 114 dasarians. This period was observed on previous study on rainfall of North Sulawesi, Sagita [6] considered quasi biennial oscillation as main factor inferred from the period. This oscillation cycle around 24 to 30 months related to zonal oscillation that changed regularly from western to eastern wind in upper level. This result agreed with a study conducted by Fleer [1] regarding rain anomalies in the tropics, spectral peaks were observed for a period of 810 days in an analysis of rainfall spectrum in Asia, Australia, Africa, and the north and south of America. Then by Heribert this period is associated with biennial oscillations which have a period of around 720 to 960 days. In addition, this period was also observed in other studies in various places, not only in the 
element of rainfall, but also observed in the results of research on temperature, pressure, and wind [1].

The sixth period observed at and 228 dasarians. This long term periods could be find as El Nino / La Nina events influence. El Nino is global phenomenon of anomalous sea surface temperature over the Central and East equatorial Pacific Ocean with quasi peiodicity of $2-7$ years. This events tipically persist for $9-12$ months, though occasionally persisting for up to 2 years. This events influenced wide rage area over the globe including Indonesian region. In El Nino events, most of Indonesia region will suffer rainfall decreases while on La Nina events, most region will receive more rainfall.

\section{Conclusion}

An analysis of rainfall periodicities in Tanjung Priok has been conducted. The result showed that rainfall pattern in Tanjung Priok was strongly influenced by Monsun with 36 dasarians of period. While spectral analysis of rainfall anomaly in the area showed six dominant spectral peaks of 19 dasarians, 31 dasarians, 3 dasarians, 42 dasarians, 114 dasarians, and 228 dasarians. These periods were indicated as the period of ITCZ, Madden-Jullian Oscillation, dipole mode, and El Nino / La Nina.

\section{References}

[1]Fleer, Heribert.: Large-Scale Tropical Rainfall Anomalies. Disertation, Mathematisch Naturwissenschaftliche Fakultat of the Rheinische Friedrich - Wilhelms - Universitatzu Bonn, page 24 (1981).

[2] Hadi, Wasito: A Study of Long Period Rainfall and Pressure Anomalies In Indonesia. Thesis,College Of Science of the University Of The Philippines (1987).

[3]Hermawan, Eddy: Penggunaan Fast Fourier Transform dalam Analisis Kenormalan Curah Hujan di Sumatera Barat dan Selatan Khususnya Saat Kejadian Dipole Mode, JMG, Vol 8, No. 2 (2007).

[4] Suryantoro, Arief: Fenomena MJO/ISO dan Hubungannya dengan Pola Aktivitas Awan Konvektif dan Curah Hujan di Lampung, Sumatera Selatan, dan Aceh, JMG, Vol.5, No.4 (2004).

[5] Hidayat, Muhammad: Analisis Curah Hujan di Bandara Soekarno Hatta Menggunakan Metode Wavelet, JMG, Vol.2 No.7 (2019).

[6] Sagita, Novria, As'ari, Wandayantolis: Analisa Spektral Data Curah Hujan di Sulawesi Utara, Jurnal Unsrat Online 2 133-139 (2013). 